\title{
Hvorfor spilde tiden med kvindelig idrætsledelse?
}

\section{Kønskonstruktioner og ligestillingsmæssige tiltag i den frivillige idrætsledelse}

\section{Af Linnea Ytting}

En kvalitativ analyse af unge frivillige idrætslederes idrætsvaner, hverdag og tanker om idræt ${ }^{1}$ viser, at problematikken vedrørende de manglende frivillige kvindelige idrætsledere drejer sig om, at kvinder skal ville magten, og at magten skal ville kvinderne. Denne artikel har til formål at vise nogle af de kønskonstruktioner, der eksisterer i idrætsorganisationerne, da de har indflydelse på kvindelige idrætslederes lyst til og muligheder for at bestride de frivillige ledelsesposter. Artiklen formidler endvidere en unders $\varnothing$ gelsesmetode, der kan benyttes af andre, der er interesseret $\mathrm{i}$ at lave tilsvarende analyser af kønnets betydning. Derudover vil den overordnede ligestillingsdebat i de danske idrætsorganisationer blive inddraget, da den i de seneste år har taget en mere politisk drejning end tidligere, hvilket kan medføre ligestillingsmæssige forandringer i idrætsorganisationerne.

\section{Ligestilling $i$ idratsorganisationerne}

Argumentet for at få flere unge kvinder engagerede i frivillig idrætsledelse skal ses i lyset af følgende faktorer: Konkrete tal der dokumenterer problemet, de historiske aspekter, et ligestillingspolitisk synspunkt og idrætsorganisationernes $\emptyset$ nske om at engagere flere unge idrætsledere.

Der er generelt i toppen af dansk idrætsledelse en lav kvindedeltagelse. På nuværende tidspunkt sidder der 2 kvinder i Danmarks Idræts-Forbunds (DIF) bestyrelse på 10 medlemmer, og 6 kvinder har været repræsenteret igennem de over 100 år, bestyrelsen har eksisteret. Kvinderne udgør 39,2\% af medlemmerne i DIF, og det kan således opfattes som bemærkelsesværdigt, at DIF kun har 2 kvinder repræsenteret i deres bestyrelse. Man har en tilsvarende situation i Danske Gymnastik- og Idrætsforeninger (DGI), hvor $47 \%$ af medlemmerne er kvinder, men kun 3 kvinder sidder i hovedbestyrelsen ${ }^{2}$. Man finder dog flere kvinder på ledelsesposter, jo længere ned i systemet man kommer, men generelt er kvinderne underrepræsenteret på alle ledelsesposter selv i de idrætsgrene, hvor der er stor kvindedeltagelse ${ }^{3}$.

Anskuer man problemstillingen fra en historisk vinkel, finder man hurtigt ud af, at den ikke er ny. Bevægelsen »kvinder og idræt« blev i 1982 oprettet på baggrund af en kritik af kvinders manglende indflydelse på idrættens udvikling, økonomi og beslutningsprocesser. Bevægelsen iværksatte en strategi, der byggede på et $\emptyset$ nske om at få flere kvindelige deltagere og ledere $\mathrm{i}$ idrætsorganisationerne. I de efterfølgende 
år blev der blandt andet arrangeret seminarer og konferencer med deltagelse af kvindelige idrætsledere. I 1983 afsluttede seminaret med en høring, hvor pressen, idrætsforskere og daværende formand for ligestillingsrådet, Helle Degn, var indbudt. Her blev det besluttet, at DIF skulle ansætte en kvindeidrætskonsulent, som skulle udarbejde handlingsplaner med den overordnede målsætning at få flere aktive idrætskvinder og kvindelige ledere på alle niveauer. I 1985 blev roeren Hanne Petersen valgt ind i DIF's bestyrelse, hvilket styrkede kvinderepræsentationen ${ }^{4}$.

Endnu et ligestillingsmæssigt tiltag blev i 1992 iværksat, da DIF indgik i et nordisk samarbejde om en konference, der havde til formål: »At satte fokus på rekrutteringen af kvinder og fastholdelse af kvindelige idratsledere indenfor idrattens organisationer ${ }^{5}$. I evalueringen af konferencen konkluderede man blandt andet, at der i høj grad burde satses på de unge, da alle var enige om, at der var et behov for at få en ny generation ind i idrætsledelse. Man kan således tro, at der efter denne nordiske debat og 1980'ernes ligestillingstiltag er sket en ændring af kvinderepræsentationen i den frivillige idrætsledelse i DIF. Dette er ikke tilfældet. DIF valgte i 1998 at nedlægge deres ligestillingspolitik med den begrundelse, at den alligevel ikke gav nogen resultater. Hanne Petersen blev også træt af at kæmpe for ligestilling og gav ved sin afsked i 1994 udtryk for sin frustration ved at påpege, hvor vanskeligt det var at skabe forandring i DIF og arbejde i en så mandsdomineret organisation ${ }^{6}$. Går man ind på DIF's hjemmeside i dag, vil det ikke være muligt at finde oplysninger om organisationens holdning til kvinderepræsentationen i frivillig idrætsledelse.

DGI har også kun sparsomme udtalelser vedrørende deres holdning til kvinder og frivillig idrætsledelse, men nævner i deres fremtidsvisioner: »Vi skal i sarlig grad arbejde på at identificere - og andre - dele af vores tankemåder og strukturer, som g $\phi r$ det vanskeligt for kvinder at deltage $i$ frivilligt lederarbejde. «7 DGI er således opmærksom på problemstillingen, men angiver ingen løsningsforslag. DGI udtrykker endvidere et $\varnothing$ nske om fortsat at motivere gruppen af unge frivillige idrætsledere (16-24 årige), fordi de udgør gruppen af mest aktive medlemmer, der er involveret $\mathrm{i}$ frivilligt foreningsarbejde. De unge repræsenterer samtidig foreningernes næste generation, og er vigtige at fastholde, for at foreningerne har mulighed for at udvikle sig i takt med medlemmernes ønsker. DGI påpeger i denne sammenhæng, at det er problematisk, at gruppen af unge idrætsledere kun bliver på posterne i en relativ kort periode, hvorved foreningerne hele tiden er nødt til at rekruttere nye ledere samt foretage vedvarende lederpleje ${ }^{8}$.

Kulturministeriet iværksatte i 2002 et pilotprojekt med titlen: »Kortlagning af kvinders deltagelse og reprcesentation $i$ idrcettens ledende organer, samt $i$ idrcetsorganisationernes administrative ledelse." Det politiske ligestillingsmæssige argument for at gennemføre et sådan projekt, beskrives som følgende: »Regeringen beklager den lave reprcesentation af kvinder i politik, erhvervsliv og idrcet. Ressourcer går tabt, når $k \phi n s f o r d e l i n g e n$ er skcev. Desuden betyder kvinders og mands forskellige erfaringer og interesser, at vasentlige dimensioner af samfundslivet holdes ude, når kvinderne ikke deltager i beslutningerne. «9

Problemstillingen er således kommet på den politiske dagsorden, og man kan derfor formode, at der er ændringer på vej. Det er dog stadigvæk uvist, hvad resultaterne og følgerne vil blive, og en diskussion af denne politiske dimension vil være nødvendig 
for at få en helhedsforståelse af kønsproblematikken i idrætsorganisationerne.

\section{Det problematiske $k \phi n$}

Når man vil behandle kønnede problemstillinger, er det i dag meget kompliceret at tale om køn ud fra de traditionelle kønskategorier, da der findes mænd og kvinder, der lever og udtrykker sig forskelligt indenfor begge kategorier. Nogle vil således hævde, at kategorierne ikke længere eksisterer, mens andre hævder, at de eksisterer i bedste velgående. Overordnet kan tre antagelser spores i kønsdebatten ${ }^{10}$ :

1. Den første antagelse går på, at intet er ændret. Kønnet opererer på nye, mere spidsfindige måder. Vi har bare ikke gennemskuet kønnets nye form.

2. Den anden antagelse går på, at kønnets bevægelser er gået tilbage. Begrundelsen er, at de bastioner 1970ernes kvindebevægelser opbyggede, er opløst, og ingen bemærker hvad de få, som stadig beskæftiger sig med kønsrelaterede problemer, siger eller gør. Det egalitære kønssystem er således blevet den demokratiske vestlige verdens varemærke, men sideløbende styrkes det traditionelle kønssystem og myten om 1970ernes opnåelse af kønsligestilling overlever. Dette sker på trods af, at det ikke er i overensstemmelse med individers levede virkelighed.

3. Den tredje antagelse går på, at køn som kategori er uinteressant at tale om, da kategorierne mand/kvinde er så diffuse, at de ikke korresponderer med noget $\mathrm{i}$ menneskers erfaringsverden. Kønskategorierne er så gennemtrængte af andre kategorier (race, etnicitet, alder, religion, nationalitet osv.), at det ikke giver mening at tale om dem.
Det er således meget svært at have en konkret opfattelse af køn i vores i kultur, og det eneste man med sikkerhed kan sige, er,

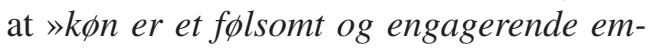
$n e{ }^{11}$. Vi har nemlig alle en engageret holdning til, hvad køn betyder, eller ikke betyder. Med dette i baghovedet, vil en undersøgelse af kønnets betydning i en given delkultur fordre, at problemfeltet behandles på en åben og fordomsfri måde.

\section{Hvordan unders $\phi g e s$ kønskonstruktioner $i$ idratsorganisationer?}

Denne unders $\emptyset$ gelses åbne og fordomsfri ${ }^{12}$ tilgang til problemstillingen består i, at der ikke på forhånd opstilles hypoteser, som $\emptyset$ nskes verificeret eller falsificeret, og der leveres ikke nogen objektiv beskrivelse af en objektiv virkelighed ${ }^{13}$. Det, denne undersøgelse leverer, er en vinkling på en social virkelighed, der er i konstant bevægelse. Kønnets betydning i idrætsorganisationerne bliver således fremanalyseret ud fra seks unge mandlige og kvindelige frivillige idrætslederes erfaringsverden, hvor det udelukkende er deres erfaringer og tanker om køn, der danner grundlag for præsentationen af kønskonstruktionerne. De unge frivillige idrætsledere repræsenterer ledelsesposter fra foreningsniveau til forbundsniveau, og er tre kvinder fra hhv. ridning, badminton og roning, og tre mænd fra hhv. sportsdans, håndbold og floorball. Datamaterialet er udarbejdet gennem fokusgruppeinterview og analysen fremstilles narrativt ${ }^{14}$, hvorved de unges fortællinger og samtaler med hinanden gør det muligt at fremvise deres levede erfaringer og konkrete forståelsesformer.

Der benyttes en metateoretisk tilgang, hvor forskellige teoretiske retninger kobles 
med det formål at danne et grundlag for at forstå relationen mellem kultur og individ, individets identitetsdannelse og kønnets betydning. Her benyttes en socio-kulturel opfattelse af, at mennesket og kulturen er gensidigt konstrueret, fordi relationen mellem individ og kultur altid skabes i gensidige udvekslingsprocesser ${ }^{15}$. Identitet kobles til individers relative frisættelse fra institutioner, idet man i det posttraditionelle samfund ikke fødes ind i bestemte samfundsmæssige placeringer, på forhånd fastlagte livsmønstre eller forventes at realisere bestemte virksomhedstilknytninger. Når frisættelsen omtales som relativ, skyldes det identitetsdannelsens afhængighed af det enkelte individs kulturelle genkendelighed og accept ${ }^{16}$. I de gensidige udvekslingsprocesser ligger også den socialkonstruktionistiske opfattelse af sproget som det generelle træk i forhandlingsprocessen, hvor man forholder sig problematiserende og analyserende i forhold til individers forståelsesformer og kategorier som f.eks. $\mathrm{k} \emptyset \mathrm{n}$, emotionalitet, rationalitet, identitet osv. I den forstand bliver vores forståelse af verden et socialt produkt $t^{17}$. Der tages her ikke højde for individers fysiske udtryk, hvilket kan være problematisk, da fysiske udtryk også udgør et vigtigt forhandlingsmedium i analyser af konstruktionsprocesserne $^{18}$. Kønnet forhandles ikke kun gennem diskursive praksisser, men bæres som noget indforstået i de kulturelle aktørers kroppe, som noget præ-refleksivt og prædiskursivt. Derfor bør det kropslige også forstås som noget performativt, idet køn er noget, der skal udføres, og kønsidentitet bliver et resultat af den gentagende citerende praksis, vi alle tager del $\mathrm{i}^{19}$. De kropslige kønsforskelle betragtes som tegn, der er stedfortrædende for den sociale konstruktion. Aktører er dermed tegnbærere med en kropsfunktion, der udpeges som al- men, mens betydningerne udpeges som samfundsmæssige og historisk specifikke. Tegnet er ikke kun noget, der opfattes fra omgivelserne. Tegnet på kroppen går også indad og angiver, hvordan en mandlig eller kvindelig aktør forstår sig selv.

Med dette i baghovedet skal vi nu vende blikket mod aktørerne i problemstillingen, de unge frivillige idrætsledere og de kønskonstruktioner ${ }^{20}$ de omgives af og tager del i.

\section{Fanomenet kvindelighed}

Begrebet mandlig og kvindelig matrix benyttes til at betegne de forholdemåder, handlemåder og interaktionsformer, der knyttes til mandlige og kvindelige aktører i en given kultur ${ }^{21}$. Begrebet er anvendeligt til at forstå kønskonstruktionerne, fordi kulturen opererer med den mandlige og kvindelige matrix som en slags personlig substans i individerne. At have umiddelbar adgang til enten den mandlige eller kvindelige matrix, er det, der »kønner« idrætsorganisationerne. Kvindelige aktører har også mulighed for at identificere sig med den mandlige matrix (eller dele den), men må i så fald forholde sig til den usammenhæng, deres omgivelser oplever dem igennem. Usammenhængen kan opstå i varierende grad og er afhængig af de strategier, de kvindelige aktører benytter ${ }^{22}$.

Vi skal i de følgende udtalelser se, hvordan to kvindelige informanter (Lene og $\mathrm{Mia}^{23}$ ) forhandler deres kvindelige kropstegn ud fra forskellige strategier. Lene betegner sig selv som »drengepige«, fordi hun ofte i ledelsessammenhænge positionerer sig i forhold til de mandlige aktører, og hun fortæller: »Jeg kan godt marke, jeg tager noget andet tøj på til møderne. At jeg ikke kommer $i$ nedringet top, fordi man gerne vil tages alvorligt. Ikke fordi jeg er 
nogen 'babe' overhovedet, men vi skal kunne diskutere på lige plan.« Lene giver udtryk for, at hvis hun udstiller sit biologiske køn, så føler hun ikke, hun kan blive taget seriøst. Bryster er i denne sammenhæng ikke kun bryster. Bryster er tegn, der henviser til bestemte handlemuligheder og balanceringsprojekter i kulturen. Lene identificerer sig således med dele af den mandlige matrix for at tage del i inkluderingsprocesserne i den frivillige ledelse.

Mia anvender andre strategier i kønskonstruktionsprocessen, idet hun benytter nogle brydninger med kulturen, der får hende til at fremstå anderledes og mindre tilpasset. Hun ønsker ikke at blive »one af the guys « i samme udstrækning som Lene, og fortæller: »Jeg elsker at gå i nederdel, og hvis de ikke kan tage mig seriфst, fordi jeg kommer i nederdel, så snakker jeg bare højere eller slår i bordet, for jeg skal nok blive hørt. Også da jeg dyrkede eliteidrat, var jeg altid den, der stod til promieoverrakkelsen iført nederdel, hvor de andre stod $i$ trceningstøj. Og selvom jeg altid har klaedt mig meget piget, så har jeg også altid varet den, der tonser fodbold i nederdel.« Mia identificerer sig i høj grad med den kvindelige matrix, og antyder, at det kan forbindes med nogle ekskluderingsprocesser, som hun bekæmper ved at snakke højere eller slå i bordet. Begge kvinders historier er bundet til de kulturelle koder for kvindelighed. Uanset hvilke strategier kvinderne benytter, bliver deres kønskonstruktioner forstået i overensstemmelse med deres kvindelige kropstegn, som de ikke kan løbe fra. Konstruktionen kvindelighed sker således gennem »den anden « (manden), som normen for det menneskelige, rationaliteten og identiteten, hvorimod konstruktionen af mandlighed (defineret som menneskeheden) er sket gennem udelukkelsen af det kvindelige. Forestillin- gen om det mandlige/kvindelige subjekt (jeget) bliver således opbygget gennem en differentieringsproces, der adskiller mandligt fra kvindeligt ${ }^{24}$.

De mandlige informanter (Poul, Tim og Asger) tager del i denne diskurs, idet de diskuterer, hvorvidt kvindelige idrætsledere repræsenterer kvindelige værdier. Poul påpeger her, at »det jo er spandende om de overhovedet reprasenterer kvindelige vardier. Eller de kvinder der virkelig er, ja undskyld jeg siger det »kvinder «, om de for laengst er skramt vaek.« Kønskonstruktionerne viser sig som noget, der ligger indlejret i mændenes tankegang. Kvinder kan godt være i frivillig idrætsledelse og enten repræsentere eller ikke repræsentere kvindelige værdier, men spørgsmålet bliver så, om de kan kategoriseres som »rigtige kvinder « med den slags kvindelighed, kulturen (især mændene) forventer at se. De rene kategorier »den rigtige kvinde « og »den rigtige mand « eksisterer således som orienteringsgrundlag i kulturen, og giver derved et billede af den fiktion de aktuelle orienteringer går op imod ${ }^{25}$. Med andre ord, er det når den nøgne kvindekrop tager kulturen på, at vi har den »kvindelige kvinde«. Det bliver derfor først, når kvinder anvender de kulturelle produkter, de bliver naturlige og sig selv. Kvindelighed handler derfor $\mathrm{i}$ bund og grund om maskerade ${ }^{26}$. Kvindekroppen er et objekt, et billede og et kunstprodukt, vi begærer, og kvindelighed bliver derved en gentagende iscenesættelse af kroppen, som gør, at kvindelighed bliver til, og derfor ikke er medfødt.

\section{Fagligheden}

Et centralt omdrejningspunkt for de kvindelige informanters samtaler og fortællinger er seriøsitet. De mandlige informanter kommer på intet tidspunkt ind på dette em- 
ne, hvilket kan skyldes, at det ikke er et vigtigt element $i$ deres forhandlingsprocesser. Lene har i den sammenhæng gjort sig nogle overvejelser omkring, hvordan hun agerer i ledelsessammenhænge, og hun fortæller: »Jeg kan godt finde på at rykke over $i$ drengelejren for at blive taget seriøst. Det er jo ikke sådan bevidst, men det er bare sådan ubevidst, at jeg tager altså ikke mit strikket $\phi j$ med til møderne. " Den ubevidste strategi Lene benytter i konstruktionsprocessen, omhandler den usammenhæng hendes kvindelige kropstegn byder hende i ledelsessammenhænge. Hun vælger derfor at positionere sig i forhold til de mandligt kropsmærkede aktører, nok primært for at opnå accept, men også fordi noget er på spil. Det, der er på spil, er faren for ikke at blive taget seriøst, hvilket endvidere forbindes med det at være ung, usikker og ikke have nogen rollemodeller af samme kropstegn at identificere sig med.

De kvindelige informanter oplever derfor, at det er svært at begå sig på ledelsesposterne, hvor de næsten udelukkende samarbejder med mænd, som ofte er ældre end dem selv ${ }^{27}$.

I modsætning til de kvindelige informanter positionerer de mandlige informanter sig ikke i forhold til deres alder. Poul betegner tværtimod sig selv som »ung af alder, men gammel af sind «, idet han definerer sine holdninger i overensstemmelse med det etablerede. Tim er enig med Poul, og udtaler: »Der er et bestemt arbejdsforum, og jeg mener ikke det diskriminerer $i$ alder. Det diskriminerer måske, ja, vi kan kalde det, det politiske udsyn til hvordan forbundet skal se ud«. Det arbejdsforum, Tim her refererer til, er styret af, hvad sociologen Pierre Bourdieu kalder organisationers maskuline forretningsgange. Disse er kendt og anerkendt af alle aktører, der tager del i strukturen, og er derved gjort le- gitime $^{28}$. De kvindelige idrætsledere orienterer sig i forhold til disse maskuline forretningsgange, som også bygger på en opfattelse af manden som »universal worker $\ll^{29}$. De kvindelige informanter bliver derved nødt til at forholde sig til den mandlige matrix som et orienteringsgrundlag, når de skal begå sig på ledelsesposterne.

Lene fortæller, at hun indimellem føler sig utilstrækkelig og usikker i det mandlige selskab. Hun påfører derfor sig selv nogle restriktioner, der får hende til at føle, at hun fremstår mere i overensstemmelse med den mandsdominerede kultur, hun er en del af. »Jeg har toenkt, når jeg stod og skulle holde et foredrag, at jeg skulle pludre lidt mindre. Jeg kan godt have en tendens til at snakke $i$ lange satninger og sådan kvidre lidt. Og det har jeg varet meget opmarksom på, jeg ikke skulle, fordi så sidder mandene og tanker 'krist'! Så, jeg snakker $i$ lidt mere korte og pracise satninger. Det kan godt vare, at det er en mandlig vardi, men jeg tror da, det giver bonus. Jeg tror, man bliver taget mere seriøst.« Lene forhandler således sit kropstegn kontekstualiseret, idet hun benytter forskellige forhandlingsstrategier, alt efter hvilken kontekst hun agerer i. I ledelsessammenhænge forhandles det $\mathrm{i}$ en over-for stilling med det maskuline som det grundlæggende, hun ubevidst forholder sig til. Lene oplever, at når hun kobler sit kvindelige kropstegn med en mere maskulin fremførelse, kan hun vinde større legitimitet i kulturen. Dette viser, hvordan identificering med den mandlige matrix bliver et orienteringsgrundlag i ledelsessammenhænge. Adgang til magt bliver af Bourdieu kendetegnet gennem $»$ kvinders dilemma $\ll$ : Hvis kvinder handler som mænd, mister de deres femininitet, og handler de som kvinder, kommer de til at virke inkompetente 
og utilpasset situationen ${ }^{30}$. Det, der kan betegnes som kvindelig adfærd, bliver således mødt med ekskluderende kræfter fra den omgivende kultur. Et eksempel på hvordan de ekskluderende kræfter også er en del af den gentagne citerende praksis, kan eksemplificeres gennem debatten om, hvorvidt kvinders overtal på universiteterne kan sænke uddannelsesniveauet: »Når studiemiljфet bliver feminiseret, kan de kvindelige vardier $^{31}$ komme til at fylde for meget. Det betyder, at den mere private og den pludrende-snakkende faglighed kan blive fremhoevet på bekostning af den konkrete, faglige viden. $\ll^{32}$

Den »pludrende-snakkende faglighed « bliver i dette betydningssystem sat overfor den konkrete faglige viden, hvorved diskursen kommer til at omhandle kvinders udtryksform som ikke-faglig og den mandlige udtryksform som den faglige. De mandlige informanter tager del i denne diskurs, og Poul fortæller: »Lige netop hvem jeg arbejder godt sammen med, og hvem jeg respekterer, når jeg sidder til moderne, det er ofte folk som har en akademisk måde at argumentere på. Så man argumenterer ud fra, det forholder sig sådan og sådan, så er der en årsagskade, og så bliver det sådan. Det kan lige så godt vare kvinder som maend. Og så er selvfфlgelig noeste spфrgsmål, om det er en mandlig måde at argumentere på? Om de bare har tillart sig at argumentere som mand? « I denne sammenhæng er de mandlige informanter enige, og det opleves endvidere som svært at takle, når argumentationsformen bliver styret af følelser. Tim fortæller: »Dem jeg har svart ved at arbejde sammen med, er dem, der lader folelser komme med ind $i$ billedet. Folelser har sin plads, men på en eller anden måde mener jeg godt, de må blive udenfor døren til et bestyrelsesmode. Jeg har varet decideret bange for at kriti- sere én, fordi hun på et tidligere tidspunkt var brudt sammen og begyndt at grade. Og det giver en helt anden kultur, som jeg $i$ hvert fald har svart ved at forholde mig til. For $i$ teorien bør jeg jo sige, hvad jeg mener uden at tage hensyn til, at der sidder en $k v i n d e . « I$ dialogen om følelser bliver de mandlige informanter enige om, at de har meget lettere ved at acceptere og takle følelser, der vises aggressivt frem for med tårer. Den aggressive adfærd kan tilskrives, hvad Bourdieu kalder de mandlige tillærte dyder $^{33}$ og sidestilles med den akademiske argumentation. Dette viser, hvordan de af kulturen bestemte maskuline dyder, kommer til at rangere over de feminine. De kvindelige og mandlige informanters samtaler og fortællinger viser, at der $\mathrm{i}$ en vis udstrækning er en indbygget formodning om, at kvinder ofte ikke er lige så kompetente i ledelsessituationer som mænd. Denne formodning skal ses i lyset af, at de kvindelige aktører i idrætsorganisationerne skal begå sig blandt mandlige aktører, der alle har den fordel, at de har umiddelbar adgang til den mandlige matrix og derfor lettere kan identificere sig med den omgivende kultur. Overordnet viser de kvindelige informanters fortællinger også, at de er vant til at være en del af de eksklusionsprocesser, der opretholder matricen. Den kvindelige matrix opleves således af kulturen, som det der kendetegnes gennem lav prestige, useriøsitet og i sidste ende det underordnede, fordi de mandlige udtryksformer rangerer over de kvindelige.

\section{Det sociale aspekt}

Fra en historisk vinkel kan man konstatere, at kvinderne siden 1870'erne har været repræsenteret i idrætten, både som aktive deltagere, men også som en del af det kulturelle liv i foreningerne, idet de stod for 
fanebroderierne, kaffebordene og det sociale liv med fester ${ }^{34}$. Det sociale element har således længe været knyttet til kvinders rolle i idrætten og er det også i dag i det frivillige arbejde. At skabe sammenhæng mellem aktiviteterne og det sociale liv er derfor i høj grad en af kvindernes bevæggrunde for at lave det frivillige ledelsesarbejde. Den mandlige informant, Asger underbygger denne opfattelse, idet han påpeger, at »det altid er kvinderne, der indfører kageordning «, hvilket efter hans mening kan sidestilles med, at kvinder stadigvæk er »moderlige«, og at der derved kommer omsorg ind i forbundene. Der er således en forventning til, at kvinderne påtager sig de sociale opgaver, men ofte bliver de sat overfor det seriøse, hvorved det sociale elements værdi kommer til at rangere underordnet. Mia fortæller, at når hun er kommet med forslag til sociale arrangementer, er hun blevet mødt med bemærkninger som: »Det er ingen kaffeklub, det er et traningscenter! « Hendes $\emptyset$ nske om at skabe et sammenhold i klubben drukner således i en modstand, der sætter spørgsmålstegn ved, hvorvidt hun arbejder seriøst. Der skelnes i denne sammenhæng mellem, hvorvidt det sociale (useriøse) skaber en kaffeklub, og det seriøse skaber et træningscenter. Det bliver herved en kvindelig værdi at $\emptyset$ nske en kobling mellem det sociale og det seriøse. Det ligger i betydningssystemet, at det udpeges som mandlighedskonstituerende at kunne adskille det faglige fra det sociale, samt det teoretiske fra det følelsesmæssige. Omvendt fungerer det som femininitetskonstituerende at være mere social og i mindre grad i stand til, at kunne adskille det sociale og det faglige, det følelsesmæssige og det seriøse. ${ }^{35}$ Den kvindelige matrix kan således i idrætsorganisationerne forbindes med ekskluderingsprocesser. Disse funge- rer ikke efter et enten/eller princip, da det ugenkendelige, ugyldige eller uacceptable ikke håndhæves gennem regelret eksklusion eller direkte sanktioner. Det håndhæves i stedet gennem en placering som kulturel underordning. Det, der af kulturen opfattes som irrelevant eller ugyldigt, kan både opleves som frastødende og irriterende, men det kan også opleves som sødt og underholdende, hvilket gør, at aktøren oplever en form for positiv respons, selvom det altid vil være placeret i forhold til det relevante og centrale.

\section{Hvorfor kvinderne ikke vil magten}

De kvindelige og mandlige informanter kommer flere gange ind på spørgsmålet om, hvorvidt kvinder egentlig har lyst til at bestride ledelsesposter. I denne sammenhæng fortæller Tim: »Det er sjaeldent, man støder på en kvinde, der er engageret og siger: Jeg vil have den post, eller jeg vil gøre et stykke arbejde. Hvis jeg skal binde en fordom med en erfaring, så er det, som om kvinderne ikke rigtig vil det. Jeg er aldrig blevet prikket på skulderen af en kvinde, som har sagt, at hun gerne vil det her.« Derudover påpeger Tim, at de kvindelige ledere, han kan komme i tanke om, ikke er ledere af egen drivkraft, men fordi der har været mangel på folk, eller fordi de er mødre til nogle af sportsudøverne.

Lene har også gjort sig nogle tanker om denne problemstilling. Hun mener, at kvinder går efter opgaver, hvor de udvikler noget sammen og er sociale med andre. Lene fortæller: »Jeg tror, jeg ville have svart ved at kampe for, at alle kvinder skulle mere til orde, fordi man jo kan komme til orde, hvis man tager ordet. Men jeg kan godt se, at systemet er uinteressant for kvinder- 
ne. Og jeg tror, at hvis der skulle vare noget, som skulle vare anderledes for kvinderne, så skulle det vare et andet system.« Tim og Lene er enige om, at problemstillingen omhandler kvinders manglende interesse for ledelsesarbejde på højt plan (dvs. forbundsniveau). Der er således ikke tale om, at der eksisterer nogle direkte barrierer, der forhindrer kvinderne $\mathrm{i}$ at bestride ledelsesposter på højt plan. Men indirekte kan der være tale om, at der eksisterer nogle eksklusionsprocesser, der gør det vanskeligt for kvinder at bestride ledelsesposterne. Dette kan sammenlignes med Bourdieus opfattelse af, hvorfor mange job i vores kultur er svære at besætte for kvinder. Han mener, at mange stillinger er skræddersyet til mænd og dermed konstrueret i modsætning til kvinder. Han argumenterer videre, at hvis en kvinde skal bestride en højtstående stilling, skal hun udover at mestre de egenskaber, der kræves i stillingsbeskrivelsen, have en række egenskaber som mænd almindeligvis vil kunne bidrage med. Bourdieu nævner, at egenskaber som fysisk natur, høj/dyb stemme, aggressivitet, selvsikkerhed, distance til rollen og naturlig autoritet alt sammen er dispositioner, som mænd gennem deres opvækst er blevet forberedt og trænet til, fordi de er mænd ${ }^{36}$. De mandlige og kvindelige informanternes udsagn om de få kvinder i idrætsledelse, kan således opfattes som endnu et led $\mathrm{i}$ den gentagne citerende praksis, hvorved maskulin dominans opretholdes gennem bidrag fra enkeltstående aktører og institutioner. Det kan således se ud som om, at idrætsorganisationerne bliver et eksempel på et system, der kommer til at »passe sig selv«, idet de reproducerer, overvåger og evaluerer sig selv.

\section{Hvorfor magten ikke vil kvinderne}

En undersøgelse af organisationskulturen i de frivillige idrætsforeninger viser, at kvinder ofte agerer $\mathrm{i}$ andre netværk end mænd og måske derfor ikke er der, hvor det sker, når der skal tilbydes ledelsesposter. ${ }^{37}$ Poul mener, at problemstillingen kan sammenlignes med, at der er for få kvindelige dommere i håndbold: »De mandlige dommere vi får, er ofte nogen, der kender en anden dommer, eller på en eller anden måde, er blevet prikket og sagt, det kunne vare fedt, hvis du var dommer. Og det kan jeg endda marke på mig selv. Jeg har en ekstrem trang til at volge folk, der ligner mig selv«. Pouls »trang « til at udpege nogen, der ligner ham selv, og Tims udtalelse om, at han aldrig har mødt kvinder, der har udtrykt et $\emptyset$ nske om at deltage i frivillig idrætsledelse, handler måske også om, at kvinder ikke har de fornødne netværk til at blive tilbudt ledelsesposterne. Men det handler også om, at de mandlige informanters holdning til kvinder i frivillig idrætsledelse i sig selv udgør nogle eksklusionsprocesser og barrierer. Det antages ofte, at de barrierer, kvinder møder på deres vej op i topposter, udgøres af et glasloft ${ }^{38}$. Ifølge glasloftsteorien kan kvinder nå til et vist niveau i organisationerne, hvorefter de støder på glasloftet. Det vil sige, at der er et usynligt loft, der er med til at vanskeliggøre kvinders reelle muligheder for at få topposter. Glasloftet er opstået gennem vores eksisterende kønskonstruktioner, hvor mænd danner grundlaget for disse glaslofter, og kvinder medvirker bevidst og ubevidst i dets opretholdelse.

Hvis ledelsesstrukturen i idrætsorganisationerne er uinteressant for kvinder, er det nærliggende at tro, at problemstillingen vil blive løst, hvis der kommer en struktur- 
ændring. Dette er, hvad sociologen og mandeforskeren Michael Kimmel betegner som et traditionelt $»$ field of assumptions: If you build it they will come $\ll^{39}$. Antagelsen er, at hvis idrætsorganisationen er opbygget, så den er attraktiv for kvinderne, så vil de naturligt komme. Der ville så være tale om en velkomstmåtte fremfor et glasloft. Det problematiske ved denne antagelse er, at der ligger en indlejret forventning om, at kvinder der kommer ind i frivillig idrætsledelse, vil opføre sig som dem, der er der i forvejen (det vil sige mændene). Kønsproblematikken i idrætsorganisationerne er mere omfattende, og man bør derfor se på organisationen som et hele bestående af individer, strukturer og barrierer. Hvis kvinder agerer i andre netværk og føler sig tiltrukket af andre opgaver end mændene, bliver den eksisterende struktur reproduceret. Idrætskulturen formidler herved en "gate-keeper $\aleph^{40}$ funktion. Det problematiske er, at gate-keeper funktionen er indbygget i strukturen, som ikke indeholder nogen eller noget helt konkret, da den er opstået gennem tidligere aktørers handlemåder og forholdemåder. Disse omstændigheder $g \varnothing r$, at kulturen kommer til at favorisere de mandlige aktører, som făr lettere ved at identificere sig med den eksisterende struktur.

\section{Kvinder $i$ frivillig idratsledelse på den politiske dagsorden}

Problematikken vedrørende de få kvinder i frivillig idrætsledelse, er nu kommet på den politiske dagsorden ${ }^{41}$. Regeringen vil gennemføre en ny ligestillingsstrategi i idrætsorganisationerne kaldet mainstreamingstrategien. Mainstreaming ${ }^{42}$ vil sige, at noget gøres til hovedstrøm. Tanken er, at strategien skal gøre køn og ligestilling til en del af samfundets eksisterende hovedstrøm, så ligestilling bliver en integreret del af små og store beslutninger. Der gives dog ingen klare retningslinjer for, hvordan strategien skal gennemføres i praksis ${ }^{43}$. Mainstreamingstrategien er således kommet oppefra-og-ned i et ønske om afdække de kønnede problemfelter gennem statistik og forskning for $\mathrm{i}$ sidste ende at kunne ændre noget. Problemet er bare, at man stadigvæk er ved det første led (statistik og forskning), og at man ikke er enige om målet. Der findes tre definitioner eller løsninger på mainstreamingstrategiens udførelse, hvor det er muligt at benytte en eller flere af $\mathrm{dem}^{44}$ :

\section{Dokumentations og analyseproces}

2. Beslutningsproces

3. Forandringsproces

Den tredje definition lægger op til resultatlighed, hvilket de to første definitioner ikke gør. I regeringens præsentation af mainstreamingprojektet i idrætsorganisationerne gives følgende opsummering: »En afdakning af barrierer for kvinders aktive deltagelse på ledelsesniveau i politik, erhverv og organisationer ${ }^{45}$. Formålet er at skaffe et grundlag til en styrket offentlig debat om, hvordan vi kan styrke kvinders indflydelse på beslutninger $i$ samfundet. Opfordring til virksomheder, foreninger og organisationer om at $\phi$ ge andelen af kvinder i beslutningsprocesserne. $\aleph^{46}$

Regeringen formulerer hermed et $\emptyset$ nske om at styrke den offentlige debat på området samt opfordrer organisationerne til at øge kvindeandelen. Der lægges hermed en tydelig distance til forandringsprocessen, idet der ikke gives konkrete bud på, hvordan disse hensigter skal realiseres. Det er i stedet op til de enkelte organisationer at 
løse problemstillingen, hvilket nok er utopisk i en organisation som DIF, hvor man kan kan spore følgende 'begejstring' for mainstreamingprojektet:

»Man [har] jo svart ved at sige nej til at deltage $i$ en unders $\phi$ gelse af reprcesentationen af kvinder på lederposter $i$ idratten, som kulturminister Brian Mikkelsen annoncerede på årsmødet. Men det var tydeligt ikke af lyst, men af nød, at Kai Holm oplyste, at DIF selvfølgelig vil deltage. ${ }^{47}$

Ovenstående gennemgang af det politiske ligestillingsmæssige aspekt i idrætsorganisationerne viser, hvor skrøbelig ligestillingsstrategien egentlig er. Det dominerende politiske signal kan nemlig med den nye mainstreamingstrategi risikere at blive reduceret til kun at kortlægge, måle og evaluere, uden at der arbejdes mod en forandringsproces.

Samtidig kan man fra et socialkonstruktivistisk perspektiv sætte spørgsmålstegn ved den reelle virkning af ligestillingsmæssige politiske tiltag. Man kan her passende citere den svenske historiker Yvonne Hirdman: »Man nedsatter da heller ikke et 'klasseudvalg' på arbejdspladsen for at andre klassekløfterne. $\ll^{48}$ Med dette citat $\emptyset$ nsker jeg at give udtryk for en skepsis overfor, hvorvidt kønsstrukturer, kønsrela- tioner og kønsforståelser, der har meget dybe rødder i kulturen, virkelig lader sig ændre gennem ligestillingsmæssige tiltag. De politiske tiltag er dog ikke helt uden betydning, da de kan have en vigtig signalværdi som ét led i den omfattende kønskonstruktionsproces, hvorigennem kulturens aktører bliver vant til at forholde sig til de kønnede problemstillinger. Implementering af kønsforskningens resultater kan gavne mainstreamingarbejdet, da denne forskningstradition i høj grad belyser samspillet mellem k $\varnothing \mathrm{n}$ og differentieringsmekanismer.

Vi har nu fulgt nogle af de kønskonstruktionsprocesser, som omgiver unge frivillige idrætsledere. Vi kan i dag mene, at » ønnet har fået lang snor $\ll^{49}$, idet køn i dag opfattes som virksom og uden fast betydning, hvorved man som enkeltaktør har mulighed for at jonglere med de personlige udtryk for køn. Men overraskende nok har de traditionelle kønskategorier stadigvæk en vis styrke $i$ idrætsorganisationerne og fungerer i høj grad som orienteringsgrundlag hos de unge frivillige idrætsledere. Det lader derfor til, at problematikken med de få kvinder i idrætsledelse stadigvæk handler om ligestilling, ekskluderingsprocesser og marginalisering.

\section{Noter}

1. Linnea Toronczyk, Livet er for kort til kvindelig idratsledelse. - En undersøgelse af kønskonstruktioner blandt unge idratsledere. Speciale fra Institut for Idræt (København, 2004).

2. Kilde: DGI's hjemmeside www.dgi.dk

3. Kilde: DIF's hjemmeside www.dgi.dk

4. Else Trangbæk m.fl., Dansk Idratsliv (København, 1995), Bind 2, s. 148.

5. Nordisk konferencerapport: Kvinder i idratsledelse. Udgivet af Danmarks Idræts-Forbund m.fl. (1992), s. 4.
6. Trangbæk (1995) s. 148.

7. DGI's fremtidsvisioner: www.dgi.dk

8. SFI undersøgelse foretaget af Knud Larsen. Vist på DGI's hjemmeside www.dgi.dk

9. Minister for ligestilling: Perspektiv og handlingsplan 2002.

10. Dorte Marie Søndergaard, Tegnet på kroppen (København, 1996), s. 10.

11. Ibid. s. 11.

12. Det fordomsfri i metoden består i, at man i interviewet ikke bringer de kønnede betydninger på 
bane, fordi denne metode i forvejen bringer intervieweren til hændelser, hvor mænd og kvinder er involveret. Man behøver ikke at spørge direkte til kønnets betydning, fordi der søges efter det indbyggede og mangfoldige i kønnede betydninger. Hanne Haavind, Kjønn og fortolkende metode. Metodiske muligheter i kvalitativ forskning, (Oslo, 2003), s. 20.

13. Jf. den modificerede udgave af grounded theory $i$ Haavind (2003).

14. Jf. Den narrative erkendelsesform: D. Polkinhorne, Narrative Configuration in Qualitative Analysis. International Journal of Qualitative Studies and Education, 8, 1 (Texas, 1995) s. 5-23.

15. James Wertch, Voises of the mind: A Sociokulturel Approach to Mediated Action (London, Sydney and Singapore, 1991).

16. Anthony Giddens, The Construction of Society: Outline of the Theory of Structuration, (Cambridge, 1984), og Modernity and Self-Identity: Self and Society in the Late Modern Age (Stanford, 1991).

17. Kenneth Gergen, Virkelighed og relationer (Virum, 1997).

18. Søndergaard (1996), s. 46.

19. Judith Butler, Gender Trouble, Feminism and the Subversion of Identity (London and New York, 1990), Bodies that Matter: On the Discursive Limits of Sex (London and New York, 1993).

20. De kønskonstruktioner, jeg viser i denne artikel, er blot et udsnit af den oprindelige undersøgelse, som består af følgende overordnede snit i datamaterialet, som også fungerer som en teoretisk forklaringsmodel: 1) Den individuelle frivillige organisationstilknytning, 2) tidsaspektet og fremtiden, 3) ambitioner og spørgsmål om kvindelig ledelse, 4) kønsaspektet, 5) værdier i den frivillige idrætsledelse og 6) ungdomsaspektet.

21. Søndergaard (1996), s. 348.

22. Ibid. s. 361.

23. En fjerde kvindelig informant medtages ikke artiklen, da hun er formand i en bestyrelse bestående af udelukkende kvinder. Hendes oplevelser og erfaringer er derfor helt anderledes end de $\emptyset$ vrige informanters, men meget interessante $i$ en mere uddybende analyse af kønskonstruktionerne.

24. Magreta Järvinen, Køn som text. - Om socialkonstruktivismens grænser, Kvinder, køn og forskning nr. 2 (1996).

25. Søndergaard (1996) s. 380.

26. Nina Björk, Fra kvindelighedens maskerade (1997).
27. Ifølge den danske magtudredning, udgør kvindeandelen kun $15 \%$ i organisationsverdenen (jf. andre organisationer), og det fastslås at den typiske repræsentant for organisationseliten, er en midaldrende mand med en gennemsnitsalder på 55 år. Annette Borchorst, Konsmagt under forandring (København, 2002).

28. Pierre Bourdieu, Den maskuline dominans (København, 1998) s 35 .

29. Joan Acker, Gendering Organizational Theory (Newbury Park, CA, 1992), s. 258.

30. Ibid. s. 76-88.

31. Hvad der menes med »kvindelige værdier« præciseres ikke.

32. Sanne Gram og Morten Crone Sejersbøl, Kvinder erobrer universiteterne, Morgenavisen JyllandsPosten 17. december 2003.

33. De tillærte dyder er en del af Bourdieus habitusbegreb. Habitus grundlægges gennem vaner, der tilegnes tidligt i barndommen og fremover fungerer som fastlagte og ubeviste handlemønstre. Bourdieu (1998) s. 35.

34. Trangbæk (1995) s. 145.

35. Søndergaard (1996) s. 294.

36. Bourdieu (1998) s. 82.

37. Nanette von der Lippe Borges, Køn og arbejde $i$ forening. En undersфgelse af organisationskulturen i en frivillig idratsforening. Magisterkonferens (Københavns Universitet, 1995).

38. Anita Trap, Mandeklub og glasloft, Kvinden og samfundet, Årg. 118 nr. 4 (2002) s. 20-23.

39. Cliff Cheng, Masculinities in Organizations. Research on Men and Masculinities. (Thousand Oaks, Calif, CA, 1996), Introduction by Michael Kimmel, s. Vii.

40. Søndergaard (1996), s. 352.

41. Jf. det i indledningen nævnte projekt, som Kulturministeriet iværksatte i 2002.

42. Begrebet kan dateres tilbage til 1985 ved den 3. verdenskonference i Nairobi. Siden 1995 har EU også benyttet mainstreamingstrategien. Man kan således læse i Amsterdam-traktaten, at EU er forpligtet til at mainstreame på fællesskabsniveau.

43. Sine Lehn og Lykke Nielsen, Mainstreaming fra strategi til praksis, Videnscenter for ligestilling (Rokilde, 2001), s. 5-6.

44. Ibid. s. 192.

45. Problemstillingen vedrørende kvinder i frivillig idrætsledelse er sidestillet med en tilsvarende situation indenfor politik og erhverv.

46. Minister for Ligestilling, Perspektiv og handlingsplan, (2002), s. 8. 
47. Janne Hallengren, Flere kvinder i DIF's bestyrelse - Utopi eller virkelighed, Idratsliv nr. 6 (2002), s. 20.
48. Anette Borchorst og Drude Dahlerup, Ligestillingspolitik som diskurs og praksis (2003), s. 24. 49. Søndergaard (1996) s. 20. 